\title{
Increasing Overall Equipment Effectiveness in Automotive Company Using DMAIC and FMEA Method
}

\author{
Ahmad Rozak*, Choesnul Jaqin, Hasbullah Hasbullah \\ Magister of Industrial Engineering, Mercu Buana University, Jakarta, Indonesia
}

Corresponding Author Email: ahmadrozak66@yahoo.com

https://doi.org/10.18280/jesa.530107

Received: 9 October 2019

Accepted: 27 November 2019

\section{Keywords:}

overall equipment effectiveness, availability, failure mode and effect analysis, DMAIC cycle, pareto diagram, cause and effect diagram

\begin{abstract}
Cylinder Block Machining Line in Indonesian automotive company has launched a worldclass company, but this company still has intention to increase the OEE value. The aim of this research was to show the application of Failure Mode and Effect Analysis (FMEA) for increasing OEE value using the DMAIC cycle (Define, Measure, Analyze, Improve and Control). Others tool to analyze this problem were Pareto Diagram and Cause and Effect Diagram. Before improvement condition, the availability average value was $90.5 \%$ from the total of production loading time. FMEA was one of tool to select the priority of the production problem that should be taken action, so it could improve the industrial operating system from the long time and frequent breakdown equipment base on highest FMEA Risk Priority Number, by additional critical components check point and feedback system to others machine for similar problem. Thus, the ITS-0015 machine that selected as observed machine could reduce the machine breakdown time from 111 became 85 minutes/month and breakdown quantity from 4.7 became 3.5 times/month. Finally, we could increase the availability value from $90.8 \%$ became $96.0 \%$ and the impact was increasing OEE value from $87 \%$ became $92 \%$.
\end{abstract}

\section{INTRODUCTION}

Increasing world car sales from 2015 until 2018 as shown in Figure 1. The biggest portion of world car sales was from Asia region with increasing $11.7 \%$ in $2016,2.9 \%$ in 2017 and $4.6 \%$ in 2018 [1]. Indonesia is one of automotive car manufacturer country in South East Asia that lead the region in automotive sector since the 1990s [2]. The other side that the production cost increased from 2016 until 2018 due to exchange rate of United States Dollar increased to Indonesian Rupiah rate, in 2016 rose by $2.0 \%$ compared to 2015 , in 2017 rose by $0.5 \%$ compared to 2016 , then in 2018 rose by $3.4 \%$ compared to 2017. The minimum wages in Indonesia also increased every year, in 2016 rose by $14.8 \%$ compared to 2015 , in 2017 rose by $8.3 \%$ compared to 2016 , then in 2018 rose by $8.7 \%$ compared to 2017 [3].

Increasing car sales will trigger the tight competition from each automotive company. To win the competition, each automotive company must increase their quality and productivity and also reduce their production cost. Yadav et al. [4] said automotive companies were facing tough challenges to improve vehicle quality and reduce product development time for new product introduction. These requirements put tremendous amount of pressure on the product development process to achieve higher customer satisfaction, improve business effectiveness, and develop higher-quality products with fewer resources in less time. Nurcahyo et al. [5] got the result of research shows that manufacturing capability significantly influences manufacturing strategy while manufacturing strategy also significantly influences performance of Indonesian automotive component manufacturer. Fragassa et al. [6] stated that the rapid evolution and the high criticality of the modern automotive market, even slight deviations in reliability targets or discontinuity in the production capability, can provoke very huge losses for a car company.

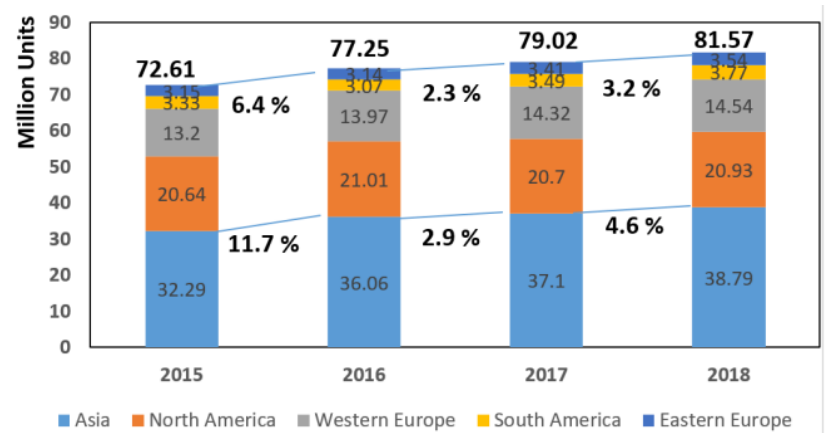

Figure 1. World car sales 2015-2018

This research continued from previous researched by Rozak et al. [7] at engine shop of automotive company in Indonesia especially at Cylinder Block Machining Line. The achievement of Overall Equipment Effectiveness (OEE) value from September till November 2018 had been over than The Japan Institute of Plant Maintenance (JIPM) standard, OEE achievement compare to world class manufacturing target can be shown in Figure 2, then we can see the achievement of OEE factors such as Availability (AV), Performance Efficiency (PE) and Rate of Quality (RQ) are compared to world class manufacturing target as shown in Figure 3.

From Figure 2, we can see that the OEE average value of Cylinder Block Machines line is $87 \%$ above the world-class 
company target of $85 \%$, although this machining line had reached world-class company level, the company continues to improve to achieve higher OEE values. From Figure 3, we can see the three factors of OEE achievement, the AV and PE values also had achieved world class company target of $90 \%$ and $95 \%$, but RQ value still below than target of $99 \%$.

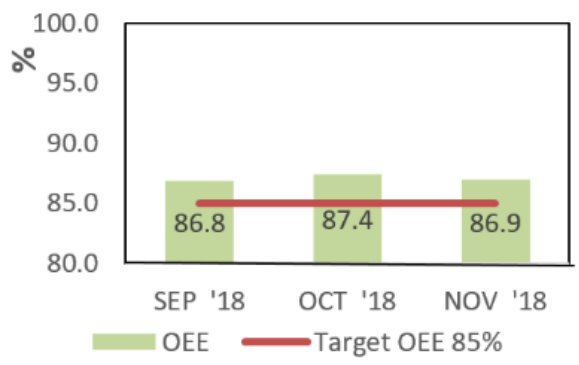

Figure 2. OEE achievement and world class target
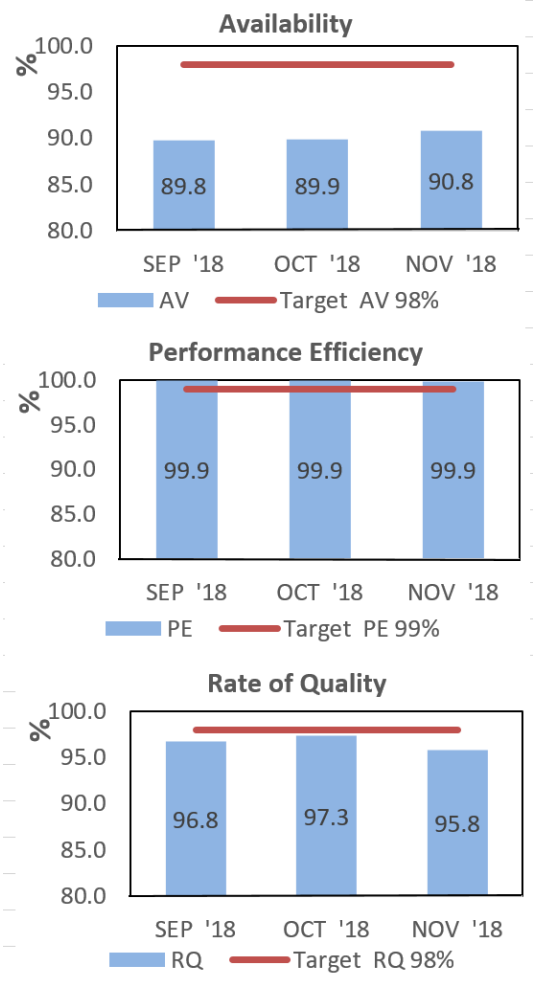

Figure 3. OEE factors achievement Vs world class target

Kumar et al. [8] researched at CNC machining of impeller factory stated that using the Overall Equipment Effectiveness technique could increase availability by $10 \%$, delivery performance increased by $14.6 \%$ and reduced waiting time by 20\%. Singh et al. [9] researched at CNC machining shop, after implementing Total Productive Maintenance (TPM) by realizing TPM Pillars and improved the losses could increase the Overall Equipment Effectiveness by 16\%. Musa et al. [10] researched at automotive component manufacturing, Crankcase line, after implementing autonomous maintenance pillar and improvement, OEE could increase by $14.6 \%$. Guariente et al. [11] researched at automotive industry, air conditioning tubes manufacturer, after implementing TPM pillars such as: autonomous maintenance, preventive maintenance and improvement, it could increase the availability value by $10 \%$ and OEE value by $8 \%$. In above researches in automotive company didn't state the detail problems linked to the which losses those could impact to the increasing availability value, and lack of the priority problem choosing, then no problem-solving step method for improvement.

Costa et al. [12] researched at Portugal Automotive industry using DMAIC cycle for process improvement could decrease $0.98 \%$ on the indicator of work-off generated by production system, financial impact could save over 165,000€ per annum. Hasibuan et al. [13] researched at chemical industry using SCOR and DMAIC method, the result of this research was supply chain performance in the textile dye case reached the highest achievement consecutively in the flexibility aspect which was $93 \%$, the cost reached $74 \%$ and the reliability achieved $72 \%$. In above researches had utilized problem solving step method for improvement, but they didn't state the detail problems those could impact to the increasing performance, and lack of the priority problem choosing.

Baynal et al. [14] researched at Turkish automotive industry stated that FMEA is widely used as an efficient decisionmaking tool to control the stability of the manufacturing process and to improve product and system performance by decreasing failure rate, the result was door seal cuts problem could solve by $96 \%$ and the noisy door window problem caused by riveting hole position, was prevented by $100 \%$. Dedimas et al. [15] researched at Ethiopia textile Share Company, using FMEA method, as a result, the company could reduce downtime and saving cost 11,466,168.00 ETB annually. FMEA methodology was used by CNC turning producer to analyze the risk involved in the operation of CNC turning center in India, by identifying critical failure modes, components and sub-systems in order to increase the quality and reliability of CNC turning center [16]. The Pareto chart is used as an important tool to identify the most significant defects by giving priority [17]. Ishikawa diagram is prior to any data analysis, every possible cause is taken into consideration, many causes are prioritized by remembering two things, first, contribution of rejection cause and second the ease with which we can solve it [18]. This research will used DMAIC cycle, Pareto diagram, Ishikawa diagram (Cause and Effect Diagram) and FMEA approach to propose the priority improvement items from the TPM problem at Cylinder Block Machining Line in automotive company in order to fulfill the weakness of predecessor researches in priority problem choosing, root causes analyzing and problem solving step.

\section{METHODOLOGY}

Researchers involved all related parties in the Cylinder Block Machining Line such as production, engineering and maintenance teams to list all relevant data and information to fulfil Failure Modes and Effects Analysis form. The framework of this study is illustrated in Figure 4. Starting from the gap between TPM Overall Equipment Effectiveness achievement and company target, there was Availability Big Problem. Base on FMEA literature review, starting from the primary and secondary data were collected from the Cylinder Block Machining Line daily report. FMEA was applied as a problem solving tool to analyze the collected data. In addition, Ishikawa diagram (Cause and effect diagram) and Pareto diagram were applied in this research to complete the analysis tool. FMEA was tabulated and then identified the failure modes, failure effect, failure cause and detection techniques. Risk Priority Number (RPN) were calculated for indicator to choose the priority of countermeasure plan. 


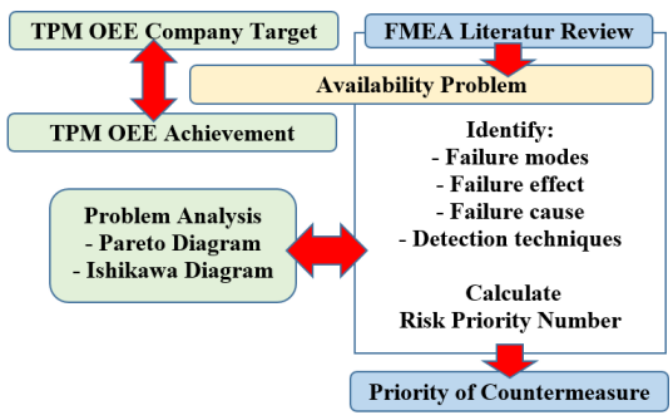

Figure 4. Study framework

\section{RESULTS AND DISCUSSIONS}

Researchers compared problem solving method between using Pareto diagram and Ishikawa diagram in previous research with combination among DMAIC cycle, Pareto diagram, Ishikawa diagram and FMEA method.

\subsection{Define phase}

During the define phase, we started to identify the initial problem at Cylinder Block Machining Line in OEE achievement compare to OEE company target as shown in Figure 5.

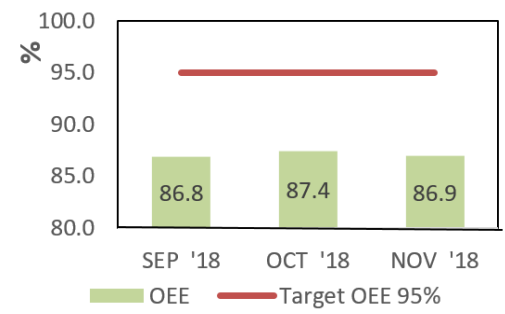

Figure 5. OEE achievement Vs company target
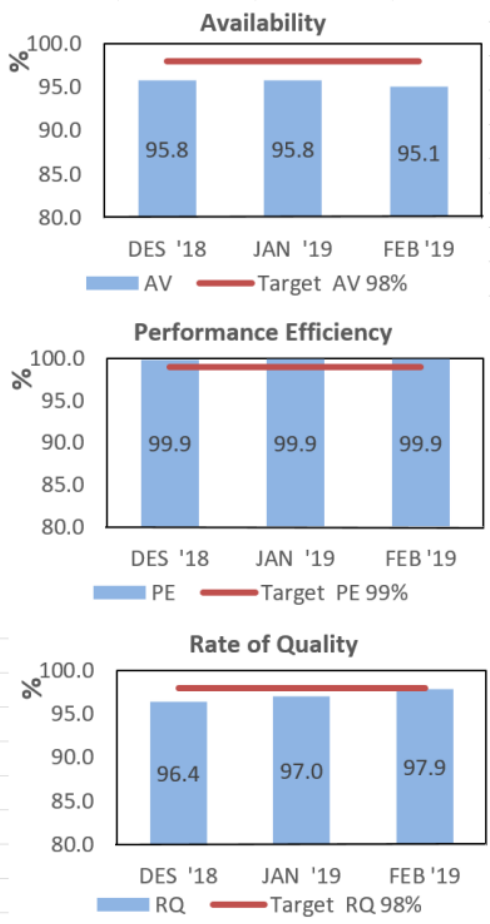

Figure 6. OEE factors achievement Vs company target
Then we can see the achievement of OEE factors such as Availability (AV), Performance Efficiency (PE) and Rate of Quality (RQ) compared to Company target as shown in Figure 6.

From Figure 6, we can see the three factors of OEE, just the PE had achieved company target $99 \%$ but AV and RQ still below the target $98 \%$. The gap between achievement and target of OEE factors can be calculated the six big losses then made Pareto diagram as shown in Figure 7, the biggest losses is Equipment Failure (EF) losses, then we will focus to EF losses for improvement.

\subsection{Measure phase}

Base on maintenance report from September until November 2018, from 85 units of equipment at Cylinder Block Machining Line, there were equipment failure happen 119 times with failure time was 2,829 minutes, we collected the equipment failure data base on long time breakdown and frequent breakdown machines, then we made Pareto diagram as shown in Figure 8 for long time breakdown machines and in Figure 9 for frequent breakdown machines.

Base on Figure 8 and 9, we selected priority machine from each Pareto diagram of three big problem machines, it was ITS-0015 Intermediate Leak Test Machine. We focused on analysing this machine for the next phase activities as it was second rank in the Pareto diagram of longest breakdown machine with a breakdown length of 111 minutes / month and it was first rank in the Pareto diagram of the most frequent breakdown machine with 5 times / month.

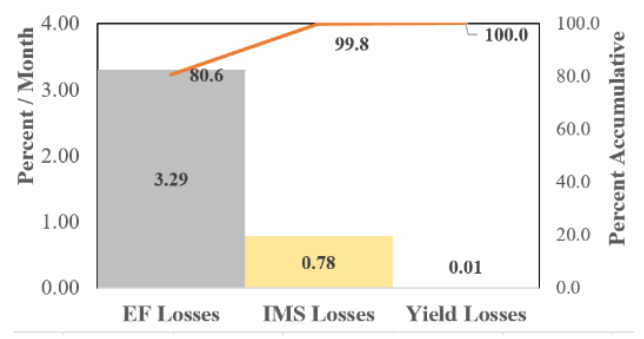

Figure 7. Six big losses pareto diagram

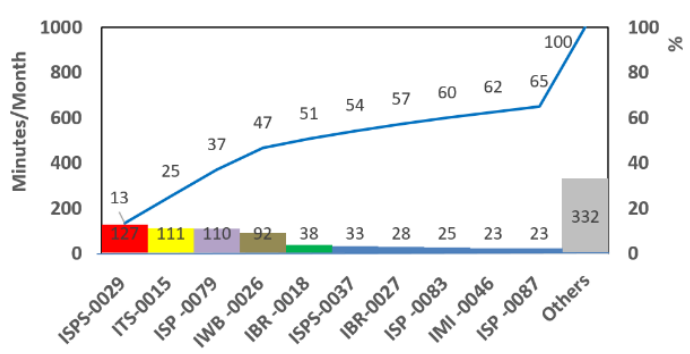

Figure 8. Long time breakdown machines pareto diagram

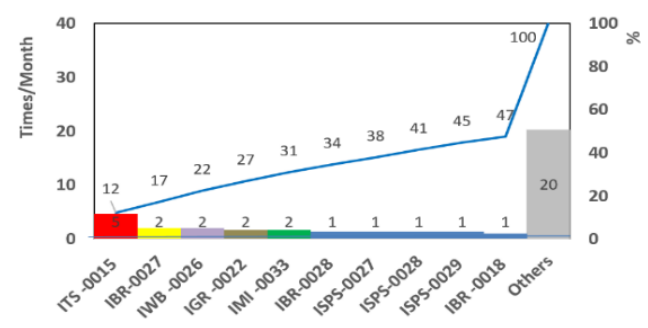

Figure 9. Frequent breakdown machines pareto diagram 


\subsection{Analyze phase}

During the Analysis phase, researchers collected data and information related to the breakdown of ITS-0015 machine from September until November 2018 as shown in the Table 1. From this table, we can see the list of problem, initial problem and problem cause. Base on Table 1 and focus group discussion among related parties in engine shop, such as: maintenance, engineering and production departments, we could make FMEA table as shown in Table 2. To determine rating of severity, occurrence and detection, we used focus group discussion method, then we calculated the Risk Priority Number (RPN) value by following formula:

$\mathrm{RPN}=$ Severity $\mathrm{x}$ Occurrence $\mathrm{x}$ Detection

Table 1. ITS-0015 failure equipment problem list

\begin{tabular}{|c|c|c|c|c|}
\hline No. & Problem & Initial Problem & Problem Cause & Remark \\
\hline 1 & Oil hole improper was fault & Air cylinder hose was leakage & Hose was out of date & --- \\
\hline 2 & Masking return wasn’t end & Dog touched proximity switch & Bolt was loose & --- \\
\hline 3 & Oil filter Jig position wasn't end & Proximity jig oil filter wasn’t on & Proximity switch was broken & --- \\
\hline 4 & Oil hole improper was fault & There was water in Air filter of Oil hole & Hose was out of date & Repeat cause from No. 1 \\
\hline 5 & Oil hole improper was fault & Air cylinder hose was leakage & Hose was out of date & Repeat cause from No. $1 \& 4$ \\
\hline 6 & Oil hole improper was fault & Upper rubber was torn & Rubber was out of date & --- \\
\hline 7 & Oil hole test was fault & Oil hole pressure was drop & Regulator was broken & --- \\
\hline 8 & Oil hole improper was fault & Regulator filter was wet & Regulator filter was broken & --- \\
\hline 9 & Oil hole charging was fault & Cosmo Oil hole wasn't on & Mechanical valve was broken & --- \\
\hline 10 & Oil hole charging was fault & Cosmo Oil hole wasn't on & Mechanical valve was broken & Repeat problem from No. 9 \\
\hline 11 & Oil hole improper was fault & Booster air was drop & Mechanical valve was broken & Repeat cause from No. $9 \& 10$ \\
\hline 12 & Oil hole test was fault & Regulator filter was wet & Regulator filter was broken & Repeat cause from No. 8 \\
\hline 13 & Crank fault & Crank hole rubber was torn & Bolt was loose & Repeat cause from No. 2 \\
\hline 14 & Oil hole improper was fault & Regulator pilot pressure was leakage & Regulator filter was broken & Repeat cause from No. $8 \& 12$ \\
\hline
\end{tabular}

Table 2. FMEA breakdown ITS-0015 machine

\begin{tabular}{|c|c|c|c|c|c|c|c|c|c|}
\hline No. & $\begin{array}{c}\text { Potential Failure } \\
\text { Mode }\end{array}$ & $\begin{array}{l}\text { Potential Effect of } \\
\text { Failure }\end{array}$ & $\begin{array}{c}\text { Potential Cause of } \\
\text { Failure }\end{array}$ & Remark & $\begin{array}{l}\text { Current Design } \\
\text { Controls }\end{array}$ & 离 & ֻٕ & 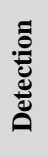 & $\begin{array}{c}\text { Risk Priority } \\
\text { Number (RPN) }\end{array}$ \\
\hline 1 & $\begin{array}{c}\text { Air cylinder hose was } \\
\text { leakage }\end{array}$ & $\begin{array}{l}\text { Oil hole improper } \\
\text { was fault }\end{array}$ & Hose was out of date & $*$ & Visual & 4 & 7 & 6 & 168 \\
\hline 2 & $\begin{array}{l}\text { Dog touched } \\
\text { proximity switch }\end{array}$ & $\begin{array}{l}\text { Masking return } \\
\text { wasn't end }\end{array}$ & Bolt was loose & $*$ & Visual & 4 & 4 & 6 & 96 \\
\hline 3 & $\begin{array}{l}\text { Proximity jig oil filter } \\
\text { wasn't on }\end{array}$ & $\begin{array}{c}\text { Oil filter Jig } \\
\text { position wasn't end }\end{array}$ & $\begin{array}{c}\text { Proximity switch was } \\
\text { broken }\end{array}$ & --- & Function & 4 & 8 & 8 & 256 \\
\hline 4 & $\begin{array}{l}\text { There was water in Air } \\
\text { filter of Oil hole }\end{array}$ & $\begin{array}{l}\text { Oil hole improper } \\
\text { was fault }\end{array}$ & Hose was out of date & $\begin{array}{c}\text { Repeat cause from } \\
\text { No. } 1\end{array}$ & Visual & 4 & 7 & 6 & 168 \\
\hline 5 & $\begin{array}{c}\text { Air cylinder hose was } \\
\text { leakage }\end{array}$ & $\begin{array}{l}\text { Oil hole improper } \\
\text { was fault }\end{array}$ & Hose was out of date & $\begin{array}{l}\text { Repeat cause from } \\
\text { No. } 1 \& 4\end{array}$ & Visual & 4 & 7 & 6 & 168 \\
\hline 6 & Upper rubber was torn & $\begin{array}{l}\text { Oil hole improper } \\
\text { was fault }\end{array}$ & $\begin{array}{c}\text { Rubber was out of } \\
\text { date }\end{array}$ & -- & Visual & 4 & 7 & 6 & 168 \\
\hline 7 & $\begin{array}{l}\text { Oil hole pressure was } \\
\text { drop }\end{array}$ & $\begin{array}{l}\text { Oil hole test was } \\
\text { fault }\end{array}$ & $\begin{array}{l}\text { Regulator was } \\
\text { broken }\end{array}$ & --- & Function & 4 & 8 & 8 & 256 \\
\hline 8 & $\begin{array}{c}\text { Regulator filter was } \\
\text { wet }\end{array}$ & $\begin{array}{l}\text { Oil hole improper } \\
\text { was fault }\end{array}$ & $\begin{array}{c}\text { Regulator filter was } \\
\text { broken }\end{array}$ & $*$ & Visual & 4 & 8 & 7 & 224 \\
\hline 9 & $\begin{array}{l}\text { Cosmo Oil hole wasn't } \\
\text { on }\end{array}$ & $\begin{array}{l}\text { Oil hole charging } \\
\text { was fault }\end{array}$ & $\begin{array}{l}\text { Mechanical valve } \\
\text { was broken }\end{array}$ & $*$ & Function & 4 & 7 & 8 & 224 \\
\hline 10 & $\begin{array}{l}\text { Cosmo Oil hole wasn't } \\
\text { on }\end{array}$ & $\begin{array}{c}\text { Oil hole charging } \\
\text { was fault }\end{array}$ & $\begin{array}{l}\text { Mechanical valve } \\
\text { was broken }\end{array}$ & $\begin{array}{l}\text { Repeat problem } \\
\text { from No. } 9\end{array}$ & Function & 4 & 7 & 8 & 224 \\
\hline 11 & Booster air was drop & $\begin{array}{l}\text { Oil hole improper } \\
\text { was fault }\end{array}$ & $\begin{array}{l}\text { Mechanical valve } \\
\text { was broken }\end{array}$ & $\begin{array}{l}\text { Repeat cause from } \\
\text { No. } 9 \& 10\end{array}$ & Function & 4 & 7 & 8 & 224 \\
\hline 12 & $\begin{array}{c}\text { Regulator filter was } \\
\text { wet }\end{array}$ & $\begin{array}{l}\text { Oil hole test was } \\
\text { fault }\end{array}$ & $\begin{array}{c}\text { Regulator filter was } \\
\text { broken }\end{array}$ & $\begin{array}{c}\text { Repeat cause from } \\
\text { No. } 8\end{array}$ & Visual & 4 & 7 & 7 & 196 \\
\hline 13 & $\begin{array}{c}\text { Crank hole rubber was } \\
\text { torn }\end{array}$ & Crank fault & Bolt was loose & $\begin{array}{l}\text { Repeat cause from } \\
\text { No. } 2\end{array}$ & Visual & 4 & 4 & 6 & 96 \\
\hline 14 & $\begin{array}{c}\text { Regulator pilot } \\
\text { pressure was leakage }\end{array}$ & $\begin{array}{l}\text { Oil hole improper } \\
\text { was fault }\end{array}$ & $\begin{array}{c}\text { Regulator filter was } \\
\text { broken }\end{array}$ & $\begin{array}{l}\text { Repeat cause from } \\
\text { No. } 8 \& 12\end{array}$ & Function & 4 & 8 & 7 & 224 \\
\hline
\end{tabular}

Furthermore, we selected the priority problems that would be improved base on the two highest RPN. There were two highest RPN, 256 with two potential causes of failure points and 224 points with five potential causes of failure. We used Ishikawa diagram in order to find out the root cause. From Table 2, we summarized the problem causes from seven items become one item is component was broken:

- Proximity switch was broken $\rightarrow$ Component was broken

- $\quad$ Regulator was broken $\rightarrow$ Components was broken
- Regulator filter was broken $\rightarrow$ Component was broken

- Mechanical valve was broken $\rightarrow$ Component was broken.

- Mechanical valve was broken $\rightarrow$ Component was broken and repeat problem cause.

- Mechanical valve was broken $\rightarrow$ Component was broken and repeat problem cause.

- Regulator filter was broken $\rightarrow$ Component was broken and repeat problem cause. 
Base on above summarized problems, there were two big problems, they were repeat potential cause of failure, such as: twice regulator filter was broken and three times mechanical valve was broken. Discussion among Maintenance, Engineering and Production Department decided that we needed additional item for problem cause was "Repeat problem happen." The team proposed that the main problem in Ishikawa diagram was ITS-005 machine has long time and frequent breakdown, then the first problem cause was "Component was broken" and the second one was "Repeat problem happen." We can see the Ishikawa diagram in Figure 10. The repeat potential causes of failure, such as: twice regulator filter was broken and three times mechanical valve was broken.

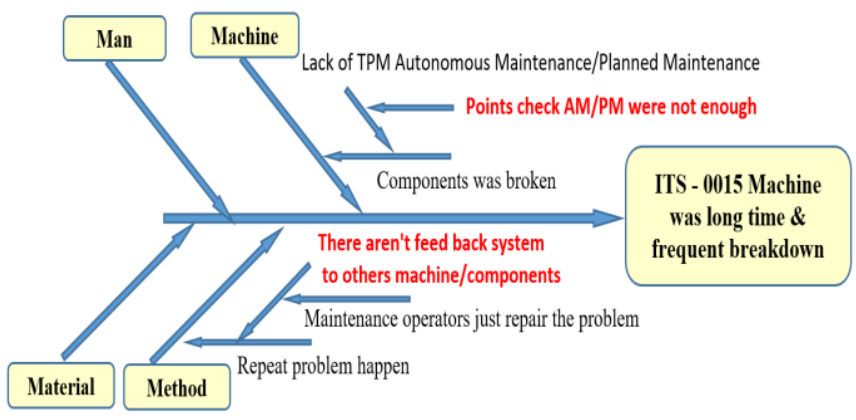

Figure 10. Ishikawa diagram for ITS-005 machine

\subsection{Improve phase}

From Table 2, we found the priority problem to be tackle base on highest RPN value, and from Figure 10, we found root causes of each problem using Ishikawa diagram. There were two types of activity plan, such as additional AM/PM point check for critical components those frequent problem and did feedback system to others component in same machine or others machine with similar condition. We could propose the plan of countermeasure for equipment failure losses problem as shown in Figure 11. The first improvement was done in the beginning of December 2018 then the second one was done in the middle of December 2018.

\begin{tabular}{|c|c|c|c|c|c|}
\hline No & Activities & Nov' 18 & Des '18 & Jan '19 & Feb '19 \\
\hline \multicolumn{6}{|c|}{1 Preparation } \\
\hline & - Data Observation & \begin{tabular}{|c|}
+1.1 .10 \\
\end{tabular} & & & \\
\hline & - Problem Analysis & $\square$ & $\square$ & & \\
\hline \multicolumn{6}{|c|}{2 Countermeasure } \\
\hline & - Additional AM/PM point check & & $\square$ & & \\
\hline & - Repeat problem feed back & & $\square$ & & \\
\hline & Result Evaluation & & & & \\
\hline
\end{tabular}

Figure 11. Improvement schedule

\subsection{Control phase}

After implementing improvement in December 2019, by additional critical components check point and feedback system to others machine for similar problem. Thus the ITS0015 machine that selected as observed machine could reduce the breakdown time from 111 minutes/month became 85 minutes/month and machine breakdown quantity from 4.7 times/month became 3.5 times/month. Feedback system also impacted to decrease others machine breakdown time. Improving all machines breakdown time from 2,418 minutes/month became 572 minutes/month. This improvement result impacted to EF losses reduction from 3.29 percent/month to 1.19 percent/month as shown in Figure 12.

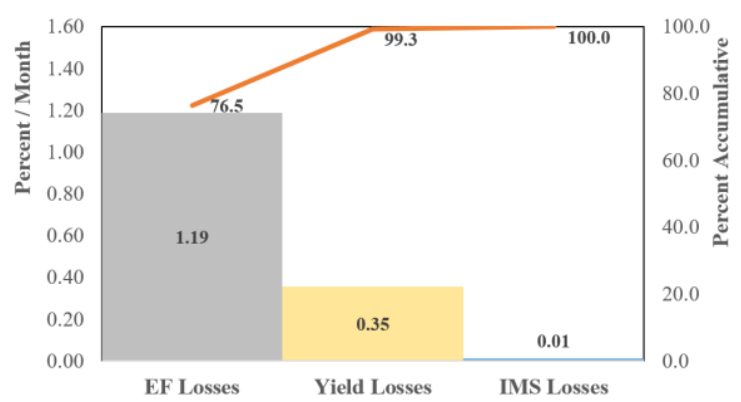

Figure 12. Six big losses after improvement availability improvement

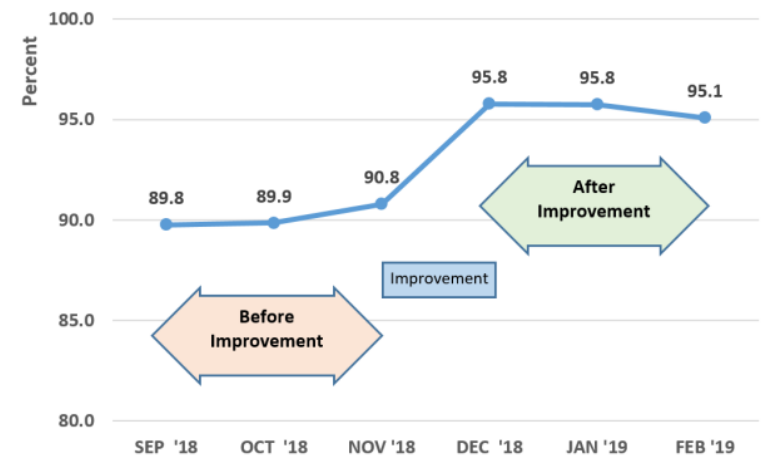

Figure 13. Availability after improvement

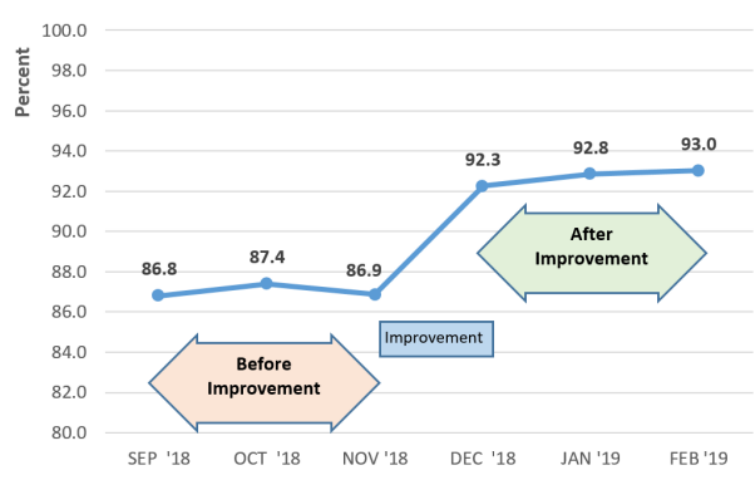

Figure 14. OEE improvement

Decreasing the EF losses could increase the availability value from average $90.1 \%$ became $95.8 \%$ as shown in Figure 13. Finally OEE value could increase from $86.9 \%$ in November 2018 to $92.3 \%$ in December 2018 as shown in Figure 14. This increasing OEE value impacted from increasing availability value. Increasing OEE in January till February 2019 due to there was rate of quality improvement activity.

\section{CONCLUSIONS}

This research shows that we could contribute to TPM performance in this Cylinder Block Machining Line by increasing of Availability value from $90.1 \%$ became $95.8 \%$ in December 2018 and finally we could increase the OEE value from $87 \%$ became $92.3 \%$ in December 2018 by improving 
following activities base on the highest RPN number: (1) Additional PM control item for frequent broken components. (2) Additional AM and PM control item for old hose. (3) Establish feedback system for similar broken component in the same machine or others machine.

The findings of this paper indicated that the application of FMEA in this analysis of breakdown machine problems was more focused than in the analysis using the Cause and Effect diagrams and Pareto diagram tools only. Therefore, Engine shop machining section is recommended to apply FMEA method in its several machining lines in order to reduce the high RPN factor points as follows: severity, occurrence and detection. This method will focus for improving the priority failure mode for maintenance cost effectiveness.

Researchers hope that others researcher can continue to do the research that relate to the increasing of Overall Equipment Effectiveness using others method.

It is mandatory to have conclusions in your paper. This section should include the main conclusions of the research and a comprehensible explanation of their significance and relevance. The limitations of the work and future research directions may also be mentioned. Please do not make another abstract.

\section{REFERENCES}

[1] Sari, P.K., Purwadinata, A. (2019). Analysis characteristics of car sales in E-commerce data using clustering model. Journal of Data Science and Its Applications, 2(1): 19-28.

[2] Ofreneo, R.E. (2016). Auto and car parts production: can the Philippines catch up with Asia? Asia Pacific Business Review, 22(1): 48-64.

[3] Utomo, A.P. (2019). UMR Jakarta 2019, 2018, 2017 Lengkap Hingga Tahun 1997. http://www.gajiumr.com/umr-jakarta/, accessed on November 25, 2019.

[4] Yadav, O.P., Goel, P.S. (2008). Customer satisfaction driven quality improvement target planning for product development in automotive industry. International Journal of Production Economics, 113(2): 997-1011. https://doi.org/10.1016/j.ijpe.2007.12.008

[5] Nurcahyo, R., Wibowo, A.D. (2015). Manufacturing capability, manufacturing strategy and performance of Indonesia automotive component manufacturer. Procedia CIRP, 26: 653-657. https://doi.org/10.1016/j.procir.2014.07.046

[6] Fragassa, C., Pavlovic, A., Massimo, S. (2014). Using a total quality strategy in a new practical approach for improving the product reliability in automotive industry. International Journal for Quality Research, 8(3): 297-310.

[7] Rozak, A., Shadrina, A., Rimawan, E. (2019). Kaizen in world class automotive company with reduction of six big losses in cylinder block machining line in Indonesia. International Journal of Innovative Science and Research Technology, 4(7): 339-344.

[8] Kumar, S.V., Mani, V.G.S., Devraj, N. (2014).
Production planning and process improvement in an impeller manufacturing using scheduling and OEE techniques. Procedia Materials Science, 5: 1710-1715. https://doi.org/10.1016/j.mspro.2014.07.360

[9] Singh, R., Gohil, A.M., Shah, D.B., Desai, S. (2013). Total productive maintenance (TPM) implementation in a machine shop: A case study. Procedia Engineering, 51: 592-599. https://doi.org/10.1016/j.proeng.2013.01.084

[10] Musa, M.A., Kasim, N.I., Razali, A., Ishak, M., Wan Saidin, WA.N. (2015). Improvement of overall equipment effectiveness (OEE) through implementation of autonomous maintenance in crankcase line. Applied Mechanics and Materials, 761: 165-169. https://doi.org/10.4028/www.scientific.net/amm.761.16 5

[11] Guariente, P., Antoniolli, I., Ferreira, L.P., Pereira, T., Silva, F.J.G. (2017). Implementing autonomous maintenance in an automotive components manufacturer. Procedia Manufacturing, 13: 1128-1134. https://doi.org/10.1016/j.promfg.2017.09.174

[12] Costa, T., Silva, F.J.G., Ferreira, P.L. (2017). Improve the extrusion process in tire production using Six Sigma methodology. Procedia Manufacturing, 13: 1104-1111. https://doi.org/10.1016/j.promfg.2017.09.171

[13] Hasibuan, S., Dzikrillah, N. (2018). Supply chain performance measurement and improvement for Indonesia chemical industry using SCOR and DMAIC method. Saudi Journal of Engineering and Technology (SJEAT), (3): 146-155. https://doi.org/10.21276/sjeat.2018.3.3.5

[14] Baynal, K., Sari, T., Akpinar, B. (2018). Risk management in automotive manufacturing process based on FMEA and grey relational analysis: A case study. Advances in Production Engineering and Management, 13(1): 69-80. https://doi.org/10.14743/apem2018.1.274

[15] Dedimas, T., Gebeyehu, S.G. (2019). Application of failure mode effect analysis (FMEA) for efficient and cost-effective manufacturing: A case study at Bahir Dar textile share company, Ethiopia. Journal of Optimization in Industrial Engineering, 12(1): 23-29. https://doi.org/10.22094/joie.2018.556677.1533

[16] Patil, R.B., Kothavale, B.S. (2018). Failure modes and effects analysis (FMEA) of computerized numerical control (CNC) turning center. International Review of Mechanical Engineering, 12(1): 78-87. https://doi.org/10.15866/ireme.v12i1.14156

[17] Ahmed, M., Ahmad, N. (2011). An application of pareto analysis and Cause-and-Effect Diagram (CED) for minimizing rejection of raw materials in lamp production process. Management Science and Engineering, 5(3): 87-95.

https://doi.org/10.3968/j.mse.1913035X20110503.320

[18] Bhagwat, M.M., Desale, D.K., Khatib, S.M., Ganu, A.E., Avaghade, S.S. (2014). Cause and effect analysis for the productivity improvement of TORNOS sigma 20II: A case study. International Journal of Emerging Technology and Advanced Engineering, 4(11): 245-250. 